\title{
Beyond the Language of Covid-19: Transformation of Social Discourse and Reproduction of Cultural Capital
}

\author{
Olena V. Gayevska* \\ Olena Y. Zhyhadlo \\ Olena O. Popivniak \\ Iryna O. Alyeksyeyeva \\ Tetyana A. Chaiuk \\ Taras Shevchenko National University of Kyiv, \\ Volodymyrska St, 6o, Kyiv, o1033, Ukraine \\ *Corresponding Author
}

DOI: https://doi.org/10.36941/ajis-2022-0oo4

\section{Abstract}

The research draws on the concept of 'cultural capital' as well as assumptions of critical discourse analysis and cognitive linguistics to argue that the Covid-19 pandemic may be viewed as a global turning point. The article explores the context and the means that have facilitated the transformation of cultural capital during the coronavirus outbreak. The dramatic changes to culture have been successfully pushed through due to the public's incessant exposure to institutionalized, governmental and mass media discourses, which have been urging people to adopt new communicative and cultural practices with a varying degree of argumentation and imposition. The changes entail reviewing social structure, spatial and relational stereotypes and standards, which in the long run transforms cultural capital. The global scope of the pandemic and the relatively identical regulations imposed by governments on their citizens generate a tentative tendency to cultural convergence: individuals are made to abandon their culture specific practices and values and adopt those that ensure physical survival.

Key words: Covid-19 pandemic, discourse, cultural capital, semiotics, communicative and cultural practices

\section{Introduction}

Dominating the global agenda for more than a year, the Covid-19 pandemic has been paving the way for a new political, economic and socio-cultural reality. The narrative of the disease shapes a new cultural milieu where outbreak-related meanings transform public discourse, the social structure, legislation and institutions. The changes brought by the pandemic are not voluntary, but rather traumatically compelled by a compilation of powers that have fractured pre-pandemic social and value representations at the collective and personal levels. All the coerced transformations have their affect-laden imagery in the human representations and practices that constitute cultural capital of 
individuals and communities.

The pandemic has already drawn a myriad of studies that analyze the changes caused by the global crisis at political, economic and socio-cultural levels in different parts of the world. Studies vary in terms of their scope. For example, (Alkhamshi, bin Shalhoubm, Hammad, \& Alshahrani, 2021) have carried out an insightful research into the psychological, social, and economic effects the Covid19 pandemic has on Saudi society; (Mansor, Ab Rahman, Azza, Abd Rashid, \& Ain Chua, 2021) concentrate on 'the new normal' that results from online teaching and learning in a Malaysian university; (Abdul Rashid, Hassan, Md. Sharif, Abd Rahman, \& Mahamud, 2021) focus on studying the tools of digital marketing employed by small businesses in Malaysia during the Movement Control Order imposed by the government in order to flatten the curve; state security issues entailed by the pandemic within the legal system of Italy, Australia and Malaysia are discussed in (Osman, Hassan, Tajudin, \&@ Ali, 2021).

There are also numerous studies that approach the changes as a global trend. Cultural modifications, for example, are discussed in (Honey-Rosés et. al., 2020, p. 2) who argue for a "tectonic shift" that is modifying "the fundamental principles and rules" of human practices. Demertzis and Eyerman (2020), in their turn, describe the collective "compressed cultural trauma" that has been triggered by the Covid-19 crisis and that is currently threatening the very core of the societal fabric by globally reshaping subjectivities of both individuals and communities. Alexander and Smith (2020) claim that the semiotic-spatial segregation the pandemic has precipitated is restructuring the sociocultural milieu and its cognitive representations owing to shifts in language, metaphors and everyday life. Other scholars point out the changes in the semiotic perception of visual representations (Leone, 2020; Ricca, 2020) as well as transformed human-public space relationship (Alter, 2020; Florida, 2020; Roberts, 2020). (Venuleo, Marinaci et al., 2020) go further by describing the crisis as "a turning point" that impacts on the social and public sphere and the whole "world scenario" soliciting new interpretations of human values and priorities (p. 7).

\section{Theories and Framework}

\subsection{The Pandemic Rupture of Social and Normative Structures}

The pandemic outbreak has effected a rapid change in the social guidelines that underlie human societies. A forced dramatic change egressed from a quandary like the Covid-19 pandemic produces fractures in the equilibrium of social and normative structures (de la Sablonnière, 2017, p. 12) begetting doubts in values and beliefs, disrupting social behavior and cultural practices, increasing moral blackmail and undermining trust and empathy. This sudden rupture of social and normative structures launches a new set of meanings, interpretations as well as "opens to a new way of being-inthe-world" and a state of "reconsidering social and personal priorities" (Venuleo, Marinaci et al., 2020, p. 9).

Hermeneutically speaking, this rampant mutation results in reconceptualization and redefinition of past social and cultural structures accompanied by the reconstruction of something new that adjusts to the changes while making sure that the old adaptive capacities have been surpassed (de la Sablonnière et al., 2009, p. 325). It is natural that this will not lead only to transmutation on the level of society, when one type will be replaced with the other (Weinstein, 2010). The society members will also experience this transmutation (de la Sablonnière, 2017, p. 12). This is likely to culminate in a redefinition of the "habitus", in the Bourdeuian sense, or in other words, cultural capital (i.e., values, relations, norms, habits, etc.) through abandoning some old skills, changing values and definitions, which in turn "lead to new patterns of behavioral development", which "shift in predictable ways to adapt to the new conditions" (Greenfield, 2016, p. 84).

Anthropologically and culturally apprehending, "[s]ocial norms and attitudes can shift in a matter of decades or years" (Varnum \& Grossmann, 2020, p. 956). However, the Covid-19 outbreak has projected "a novelty that was strange, disruptive, and dangerous", which evoked the collective 
cognitive task that "very rapidly generated a set of stable collective representations and so became 'thinkable" (Alexander \& Smith, 2020, p. 263-64). The "heightened emotionality" resulting from the outbreak (Demertzis \& Eyerman, 2020, p.433) is backed by all kinds of powerful discourses (institutional, legal, governmental, political, scientific), and is exceptionally enhanced by the "culture of fear" (Chaiuk \& Dunaievska, 2020) fueled by all types of mass and social media, which has become a 'fact' that requires responsive social practices and actions. According to Epstein (1994), when people undergo a personal emotional experience, especially fear-stimulated, they are more likely to produce change since emotions can be a more effective impetus of habit modifications than rational thinking (Venuleo, Gelo et al., 2020). Hence, when social change subsists, the values and beliefs are threatened as the old guidelines are either absent or inconsistent with the context of the change (Lapuz, 1976). This leads to "socialization ambiguity", which threatens cultural identity of all community members (McDade \& Worthman, 2004, p. 49; de la Sablonnière, 2017, p.9). Thereby, individuals attempt to seek out new roles and try to create new cultural values and norms in order to adapt to the new context imposed by the change (Macionis, Jansson \& Benoit, 2008, p.461; Chen, 2012) or, in other words, to develop new cultural capital.

\subsection{The Concept of Culture and Bourdieu's theory of Cultural Capital}

Numerous scholars agree that the concept of culture encompasses a set of understandings, system of values, beliefs, norms, knowledge and practices shared by a group to create strategies of action (see, e.g., (Geertz, 1973; Swidler, 1986; Guiso et al., 2006; Patterson, 2010; Frame \& Ihlen, 2018; Varnum \& Grossmann, 2020). Bauman (1999, p. 28) describes culture as "simultaneously a man-made and a man-making entity" and observes culture as praxis focusing on the tension between its diatomic characteristics of inventing/preserving, novel/traditional, routine/breaking patterns, changes/monotony, unexpected/predictable (Bauman, 1999, p. xiv).

In this study, culture is defined as shared and transmitted knowledge that affects beliefs, values, ideas, norms and behaviors practiced by community members. The pre-pandemic culture and the habits-prescribing norms brought about by the coronavirus outbreak clashed, and the clash has fostered a set of cultural calibrations. The latter, however, are produced not only by the pandemic itself but also by socio-cognitive human responses to the crisis. The unexpectedness and hastiness of the pandemic, arbitrariness of its presence (Bauman, 1998, p. 24) and the tyranny of the moment (Eriksen, 2001) have opened onto a cultural shift, a new landscape of sensemaking and representations and thus, onto the evolution of cultural capital of individuals and communities.

The notion of 'cultural capital' was coined by Pierre Bourdieu, the French anthropologist and sociologist. In his seminal work The Forms of Capital, Bourdieu (1986) differentiates between the economic, social and cultural forms of capital. For the scholar, cultural capital can exist in three forms: institutionalized, objectified and embodied (Bourdieu, 1986, p. 242). Institutionalized cultural capital refers to educational qualifications, while objectified capital can be understood as product of an individual's specialized knowledge (ibid.).

The current research is concerned with embodied cultural capital that is tightly bound to Bourdieu's theory of action, which evolves around the idea of 'habitus' defined as "a set of dispositions, stances, knowhows, and so forth (discursive and non-discursive)" (Fairclough, 2003, p. 23). Bourdieu's concept of 'habitus' explains "the reproduction of structures", which is directly bound with cultural reproduction (Bourdieu, 1973, p. 71). This may include cultural participation and its practices, tastes, manners as well as means of social production which constitute a system of dispositions developed through engagement within the social order.

In the context of our research, cultural capital may be defined as social normative cognizance acquired by individuals that enables them to act and interact on a daily basis within the broader structures of a given society. This knowledge may include factual information as well as habits, manners of speech and behavior, tastes, styles of living and interaction, etc. According to Bourdieu, cultural capital is passed on in a "hidden form of hereditary transmission" and can be gained quite 
unconsciously "depending on the period" (Bourdieu, 1986, pp. 243-44) and, as Fairclough points out, "can be resistant to change" (Fairclough, 2003, p. 23). Yet, cultural capital for Bourdieu retains the capacity "to reproduce itself in identical or expanded form" (Bourdieu, 1986, p. 241). Studies suggest that cultural capital or entrenched habits, i.e., 'habitus', is more likely to be broken when people are confronted to fear and their survival is at stake (Barrett et al., 2001; Coombs et al., 2007; Venuleo, Gelo, \& Salvatore, 2020). In the case of the Covid-19 crisis, it is not only fear that has engendered the social change and cultural shift, and thus, affected cultural capital, but it is also hegemonic discourses that dominate the public sphere and aim to 'power-back' sociocultural changes to the extent that coronavirus culture has become (to borrow here from (Bourdieu, 1986, p. 252)) a "personality cult".

\subsection{Discourse, Social Change and Cultural Reproduction}

The pandemic has rapidly modified institutional discourse: international and national medical organizations urged governments to adopt restricting regulations, which the governments did and, by doing so, have got their citizens to gradually become accustomed to new social and communicative practices. Thus, Covid-19 discourse has quickly gained hegemony at the global, national and personal levels. This drastic shift of the dominant discourse has entailed reconsideration of the axiomatic ideologies and challenged ethics, social norms and values. The discourse of the pandemic has fueled a fear culture reinforced by the media that picture the virus as humanity's invisible fatal enemy, which has created a new social semiotic network (masks, gloves), spatial landscape (social distancing, quarantine, lockdown, etc.) and, thereby, responsive behavioral and discursive actions. Focused on regulations and preventive measures, the discourse has its repercussion for cultural context at the national level and has generated universal symbols translated into amenable sociocultural actions and practices. The main factor of this enhancement is the tight interconnectedness between discourse, language and culture as well as their reciprocal influence.

The representation, articulation and exercising of social practices are permanently reproduced within the social system and "each actor fundamentally perceives and describes social reality by enacting it and, in this way, transmits it to other actors in the social system" (Zucker, 1977, p. 728). These arguments provide us with the ground to contend that discourses and practices of national emergency situation, as in the Covid-19 crisis, are as powerful and contagious as the virus itself. This 'contagiousness' of discourses in 'Corona time' is boosted by all types of hegemonic power that dominate the public sphere: it is backed by powerful institutional and governmental discourses and enforced through regulatory actions. In addition, it is amplified by massive media campaigns "aimed at altering citizens' habits" (Deopa \& Forunato, 2020, p. 3). Since "mass media shape our social world and contribute to changing everyday life routines, social expectations and public discourse" (Chaiuk \& Dunaievska, 2020, p. 186), media have the capacity to "characterize the cultural milieu" (Venuleo, Gelo \& Salvatore, 2020, p. 9) and consequently, to innervate and reshape cultural capital.

Patterson (2010, p. 142) argues that "power-backed beliefs and values" have a much stronger serendipity to spread and become widely adopted as the powerful and their adherents control the access to communication channels. When the power is concentrated "in the hands of those who believe in that value" (Stinchcombe, 1968, p. 108), practices of these beliefs and values become standardized. The powerful pick out those "who share their values and other cultural preferences, and they control the process of socialization" (Patterson, 2010, p.142). Thus, when people are inundated with the dominant actors' discourses or practices, they do not only adapt to such practices, but also reflexively interact with them and "what they do is then shaped and reshaped by their representations of what they do" (Fairclough, 2003, p. 22).

According to Fairclough (2003), "social practices are inherently reflexive" and people's interactions represent their (and sometimes others') practices, "including governmental and 'expert' practices" (p.22). In the context of the Covid-19 crisis, the ought-to-be sociocultural practices are strengthened by references to experts ("Let the experts speak!"), influential communication channels (mass media, social media), political discourse and crisis-management policies (regulations, laws and 
rules), institutional discourse (medical institutions and health organizations, notably the World Health Organization) (see, for example, (Chaiuk \& Dunaievska, 2020)). This helps to force changes in the "habitus of people" (Fairclough, 2003, p. 23), and the powerful control the change by acting as "ego-ideals, as role-models" to ensure that "the cultural process they favor will be disproportionately initiated and re-enacted" (Patterson, 2010, p.142), which fits in neatly with Bourdieu's "habitus" that explains the reproduction of cultural capital.

\section{Methodology}

The research applies qualitative methods since the ambition lies in outlining the connection between discourse, language and culture during the Covid-19 pandemic. Depending on its stages, the study required different methods.

The research started with the analysis of the vocabulary items that appeared and/or gained prominence in the context of the Covid-19 pandemic. These lexemes were collected through the continuous sampling method from online mass media publications, online dictionaries and official sites of governmental institutions in English-speaking countries (the USA and the UK), Ukraine, Russia, and Japan. Then the lexical items from the sample were analyzed with the help of semantic and cognitive analysis.

While collecting the data from the Japanese sources, the research revealed peculiar Covidrelated public texts that appeared as part of linguistic landscapes in Japanese cities. The material collected from these public announcements offered a certain 'bridge' from the 'word-level' analysis to the 'discourse-level' analysis.

The second stage of the research aims to explore processes at the level of discourse and culture. To this end, the sample was considered using Critical Discourse Analysis, which involved examining the texts of the sample within their sociocultural context in order to explicate the novel norms, assumptions and behaviors that are gradually getting incorporated worldwide into cultural capital as a result of the pandemic.

\section{Results and Discussion}

\subsection{The Language of Covid-19 and the Change of Sociocultural Interpretations}

The interpretation of language, cognition and culture as interrelated phenomena goes back to the research by Franz Boas, who was among the first to talk about cultural relativity in the late $19^{\text {th }}-$ early $2 \mathrm{O}^{\text {th }}$ century. Later, the correlation between language and thinking was elaborated into the linguistic relativity theory by Sapir and Whorf, who claimed that the language of cognition determines cognition. In the middle of the $20^{\text {th }}$ century, the further development of views on language - thinking - culture correlation is related with Edward T. Hall, who stated that culture and communication are tightly bound. According to the linguist, "cultures shape our communication, and our communication in turn shapes our cultures" (Hall 1959, as cited in (Frame and Ihlen, 2018, p. 156)).

Further studies have convincingly highlighted the role of language in shaping values, behaviors, attitudes and normative structures of groups that are familiar with and localized by discourselinguistic means, socio-cognitive representations and the mental lexicon (e.g., (Wierzbicka, 1997; van Dijk, 2008; Deopa \& Forunato, 2020; Sastry \& Basu, 2020) to name just a few).

According to Patterson (2010, p. 145), "[t]he reproduction of culture is a direct result of the dynamics of communication itself and entails emergent population-level consequences of individual interactions. In the context of epidemics and their influence on cultures, this argument is supported by Sperber (1998) in his epidemiological approach to cultural evolution: the scholar considers it important to understand cognitive processes accompanying epidemics and emphasizes the role of human-made changes and their interaction with the physical environment and the propagation of ideas. 
The Covid-19 crisis has undeniably shown the interconnectedness of human communicative practices and the reproduction of culture. Consequently, there are solid reasons to argue that when a semantic path and conjectural vocabulary become part of the dominant discourse, as in the case of Covid-19 crisis, they are highly likely to impact on communicative, behavioral and sociocultural practices of the society.

\subsubsection{Cognition, society and communication in Coronaspeak}

The vocabulary of the Covid-19 pandemic offers numerous examples that support the 'social discourse - language - culture' triangle. All types of discourse (mass media, institutional, everyday informal) contain a large number of Covid-related new coinages and re-interpreted lexemes, generated in response to an emerging new reality that entails changes to cultural capital.

Linguistic analysis reveals the following tendencies: medicalization of institutional discourse (contact tracing, community spread, patient zero, super-spreader, vaccination), a novel lifestyle and social practices expressed in coronacation, covideo party, elbow bump, masked up, work from home, upperwear, zoombombing as well as new policies (donations, lockdown, social distancing, shelter in place, self-isolation, travel bubble), new formal or informal, objectively or subjectively distinguished social groups (critical/key workers, clinically vulnerable citizens, frontliners, Coronial, Covidiot, Quaranteam).

The lexical analysis of vocabulary also explicates new interpretations of heroes and villains: key workers are definitely heroes, while covidiots and covideniers are villains. This polarized projection of the "friend/foe schema" (Salvatore, et al., 2019) reflects the symbolic representation and the affectladen interpretations induced by the pandemic, which shows that perpetrators of the pandemicinduced restrictions are seen as potential threat and thus, are condemned by their community. This schematic categorization leads to an ingroup-outgroup dichotomization, which will impact on the real-world cultural practices.

The lexemes anthropause, Coronacaust, Coronapocalypse and Coronaspiracy in their turn verbalize society's attempt to conceptualize reality holistically, including causal relations between its parts (for more details, see (Alyeksyeyeva et al., 2020)).

It is noteworthy that English has become the 'language of the pandemic'. The word lockdown has been borrowed into many languages (cf., Russian and Ukrainian локдаун). Japanese has borrowed from English some pandemic-related lexemes written in the katakana script: ステイホーム 'stay home', ソーシャルディスタンス 'social distance', ロックダウン 'lockdown'. The katakana transliteration of 'remote' has been used to refer the new phenomena of the quarantine, such as リモ 一ト勤務 'remote work', リモートで飲み会に参加する 'to participate in remote party', リモート会議 'remote meeting'.

The new vocabulary verbalizes and reinforces discoursal, social, cultural practices and hence old meaningful representations are restructured in relatively new ways shaping and reflecting a new reality in people's mindset. New powerfully mediated discourses bring people together, dominate the public space and, as a result, affect the social reality and the cultural context. The affect-laden usage of the vocabulary with its specific sensemaking charge has impacted on people's 'habitus' in the Bourdeuian sense and contributes to "social life as socially (discursively) constructed as an effect of discourses" (Fairclough, 2003, p. 22).

Coronaspeak, i.e., names of objects, people, phenomena, events, discursive practices and actions, engenders and then perpetuates Coronaculture translated into a universal sensemaking and behaviors which cross borders and create symbolic universes understood and acted out by everyone and everywhere. Thus, dominating discourses globally and locally, the Covid-19 pandemic gets people engaged in what Deborah Tannen (1997) calls "involvement strategy": individuals become "sensemakers" (Tannen, 1997, p. 141). Affective semantics of the crisis (re)modulates sensemakers' mind to bring them into consistency with the preferred patterns of new meanings. Consequently, the 
change in lexicon and the re-articulation of sociocultural structures beyond the simple use of language reveals the cultural 'turning point', its "symbolic resources (e.g., meanings, cognitive schemas, values, social representations, attitudes, behavioral scripts, etc.)" (Venuleo, Gelo, \& Salvatore, 2020, p. 12) and hence people's new sensemaking patterns.

\subsubsection{Discourse Hegemony and Reviewing Cultural Practices}

Discourse changes during the pandemic include the shift from denying certain practices to taking them for granted or even insisting on them.

The shift may be observed in linguistic landscapes, namely in public announcements. In Japan, for example, where wearing masks was a culturally-rooted behavior encouraged for medical reasons even before the coronavirus pandemic (De Vries, 2020; Ryall, 2020; Tashiro \& Shaw, 2020; Tateo, 2020), the novel practice brought by the pandemic was the 'silent mode' meant to stop the virus from spreading in face-to-face interactions, when masks cannot be worn. Now urban landscapes feature the public signs that prescribe to eat silently (默食) in cafes, wear masks all the time and express emotions non-verbally with gestures and/or applause in karaoke bars (默カラ) as well as train silently in gyms (默トレーニング). In particular, Osaka Kyoiku University urges students to keep silent by traditional wording shigokinshi (私語禁止 'stop talking') as well as to avoid talking while eating or with the mask removed (飲食中（=マスクを外している時）の私語は禁止とさせていた) (Univ. Coop, 2020).

Another example is provided by the official mascot's unique posters in Katsuragi city that contain the slogan Don't talk. Eat! addressed to restaurant guests. The slogan is an allusion to Bruce Lee's famous motto Don't think. Feel! (Inou, 2021).

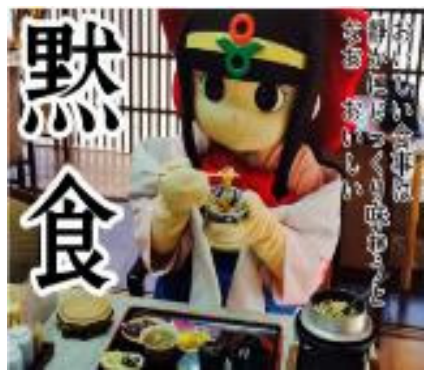

Figure 1: Renka-chan saying the slogan “Don't talk/ Eat!" (Inou, 2021)

Responsive actions of Italian immigrants to the UK are an appropriate example. After the pandemic hit Italy, the Italian government imposed severe restrictions on the population in order to prevent further coronavirus transmission. The constraints were well-grounded scientifically and backed by powerfully mediated institutional, medical and political discourses. The influence of national Italian discourse combined with Italian cultural framework was so strong that Italian immigrants living in the UK started to follow the health arrangements adopted in Italy, e.g., Italian mothers stopped sending their kids to schools (Ricca, 2020, p. 15) despite the strategy of herd immunity pursued by the British government that "focused on the in-group's power to defeat the enemy, whatever the individual sacrifice" (Venuleo, Gelo, \& Salvatore, 2020, p. 124). The Italians' behavior led to "ethnicspatial diffractions" and was considered as erroneous, i.e., inconsistent with the basic "values and principle of the UK legal system" as well as human rights (Ricca, 2020, p. 15, 17, 19). The reaction towards this behavior escalated to an intercultural conflict and discrimination, e.g., Dr. Christian Jessen, a British TV star, said that coronavirus was just "a bad cold", and Italians used the outbreak as an excuse to have a "long siesta" (Harrison, 2020). 
While the UK's national discourse of the herd immunity strategy and the intercultural disapproval of Italian immigrants' behavior by the British characterize the first phase of the pandemic, the soaring death rate proved the strategy a failure, which became even more spectacular with the Prime Minister's (who was among the main propagators of the strategy) contracting the disease. The UK government, as a result, switched to an alternative discourse, this time consistent with the global health one: British institutional and legal discourses were rearticulated so drastically that they included an unprecedented lockdown. This new discourse was backed by so-called "carrier groups", i.e., professional institutions and organizations, political, religious and other influential agents who have access to mass media (Demertzis \& Eyerman, 2020, p. 435). The new medicalized and militarized discourse, disseminated by mass media and fueling fear culture (Chaiuk \& Dunaievska, 2020), took the British public sphere into a new transitional health and security discourse. This turn transformed people's perception of the pandemic and their interpretation of Italian mothers' responsive actions and thereby altered the (inter)cultural perception of their behavior from refusal to sociocultural and legal acceptance. Promoted by powerful discourses, this change in the public opinion made Dr. Jessen, the TV star, apologize to Italians saying that he was "insensitive and offensive" (Hughes, 2020). Moreover, the rearticulation of the pandemic discourse encouraged the British to copy the Italian immigrants' protective practices.

To explain this shift to the opposite strategy during the second phase of the pandemic, it is necessary to turn to the Foucauldian concept of "pastoral power", which grasps the power relations at the institutional, economic, social and political settings of discourses that "create pathways through which meaning-making processes are transformed and/or accelerated" (Sastry \& Basu, 2020, p. 6). It also sheds light onto the way they are linked to "articulations within broad institutional frameworks (policies, laws, ideologies, cultural productions, media, etc.)” (ibid, p. 3). "Pastoral power" circulates information through communication channels controlling the accessibility of this information "to confirm or disconfirm cultural knowledge" establishing a "common ground" for shared understanding (Lyons \& Kashima, 2001, p. 374). This evolutionary scenario led "via information transmission" (Varnum \& Grossmann, 2020, p. 960) has contributed to the evolution of interpretive frameworks, cultural and ideological associations the British community applied towards the Italian immigrants' behavior. This evolutionary cultural alteration was forced by the powerful who control the process of (re)producing institutional, social and political discourses and creating desired practices that can (re)shape cultural preferences, social representations and thus, interactional behaviors of the public (Stinchcombe, 1968; Fairclough, 2003; Christakis \& Fowler, 2009; Patterson, 2010).

\subsection{The symbolic universes of Covid-19 and the Reproduction of Cultural Capital}

The Covid-19 crisis is probably one of few, if not the only, time when international discourses are molded in a global congruence. The metaphorization and translation of this universal discourse at local and individual levels, underpinned by epidemiological morphology of behaviors and objects, has entailed a transposition in what Douglas (1996) calls 'lifestyle schema'. The pandemic adaptively reshapes and accommodates the perception and meaning-making of collectivism, individualism, isolation, interconnection, social controls, spatiality, habitual practices, and behavioral acts. Besides, the crisis disseminates a new semiotic mapping of surrounding objects, urban and public landscapes, communicative patterns, connotations and denotations of signs and profoundly affects their sentimental encoding and decoding.

Breaking all ontological, geographical and cultural borders and transgressing the sociocultural orthodoxies and transforming them into a unified semiotic-intercultural architecture, the transmission of Covid-19 into human bodies has led the world into a unified global semiotic continuum (Sebeok, 2001). The translation of these universal meanings of the pandemic at the national, regional and even individual levels transformed the "habitus" of individuals from different cultures into almost a unified interracial and intercultural architecture of behaviors. The same 
semiotic appearances of the pandemic, shared by people of different cultures, values and beliefs, have helped create new symbolic universes in the individuals' cognitive mindset. These universes and commonsense are the grounding for universal cultural capital that encompasses these multiplicities and brings them under a unified umbrella of cultural deviations that will globally underpin in the post-crisis world.

\subsubsection{The Mask as a new cross-cultural visualization}

The most obvious and striking example of sociocultural deviations in the cognitive-semiotic perception that has resulted from the pandemic is the protective medical mask and the way the paradoxical meaning-affecting semiosis and ideological associations are synthesized into global cognizance. The ideological and cultural implications of the mask in the Japanese public semiotic dimension differ from those of the West in that the Japanese would avoid breathing the same air in public transport, while Westerners don't see any potential danger in the air shared with others (Leone, 2020, p. 48). Besides, the Europeans, driven by their cultural and ideological context, perceive the semiotic connotation of a hidden face in public as "different, strange and even threatening" since the masked person has something to hide from the public (ibid., p. 53). So, the ideological and cultural semiotics of the mask in these cultures is quite the opposite. While in Japan the protective mask is "a cultural configuration" (ibid., p. 51) and a sign of "the well-behaved citizen who does not want to contaminate others", Westerners interpret one's concealing one's face as an act of relinquishing one's humanity (ibid., p. 49, 53). Wearing the mask equals expressing neglect of the Western values of liberty and behavioral (communicative) norms and consequently, leads to a cultural, spatial and even ideological conflict.

Since the coronavirus outbreak, communicative practices and the semiotic architecture of social landscape have been transformed by the affective interpretation of the pandemic and this has transplanted a new semiotic apparatus and interpretive encoding. As a result, the perception of the mask has been changed and has been incorporated in Western cultural capital and its cognitive situatedness. Thus, what was culture-specific of Japanese collectivism has been assimilated in the individualistic European culture and has even become a set of cross-cultural norms underpinning the standards, aesthetics and ethics of sociocultural behavior and interactional practices not only in Europe, but worldwide.

The powerfully backed re-characterization and re-functulization of the mask and its experiential dimension within the public sphere have re-modeled the semiotic and connotative sensemaking of the masked person from 'weird, suspicious, contagious and threatening' to 'a civic, trusted active citizen, who is fighting against the spread of the virus and protecting self, family and community members and is, therefore, socially responsible and morally irreprehensible'. Hence, the morphological features of the mask which was a means of cultural/spatial conflict and differentiation (Ricca, 2020, p. 15) in European cultural and semiotic continuum have become "a supper-ordered framework" that underlines the common good of the collective interest (Venuleo, Gelo \& Salvatore, 2020, p. 125). During the pandemic, wearing the mask is an inextricable part of sociocultural norms, ethics, a moral duty and law-abidance.

\subsubsection{Covid-19 signs and their semiotic re-perceptualization}

The pandemic has affected the semiosis and the network of signs in that it has turned human bodies into a potential weapon likely to bring lethal danger. This has caused a radical change of communicative patterns and behavior, expressed, for example, in proxemics of interpersonal encounters. In other words, it has changed the meaningful and axiological translation of sociospatiality into a pandemic reading, perceptual and communicative proxemics. This semiotic and experiential metamorphosis (Ricca, 2020, p. 20) has led to a new understanding and perception of spatial, inter-bodily space in face-to-face verbal and non-verbal (handshakes, kisses, hugs, etc.) communication (ibid, p. 18). As a result, the tacit freedom of behavior is compromised to health 
and/or survival claims. We may expect these new communicative patterns and norms to be enforced and ultimately to take root even in the post-pandemic phase.

Within the settings created by Covid-19, the "hyper-dens sign" that stands for the whole social life is used by discourses and practices encompassing cultural and psychological contexts (Venuleo, Gelo \& Salvatore, 2020, 2020, p. 124). The signs of the pandemic, namely 'death', 'contagion', 'crisis”, 'fear', 'anxiety', 'solidarity', 'individualistic and collective interests', 'behavior', 'war', 'hope', etc., have prevailed all discourses (scientific, social, political and economic) with their affect-laden connotation. Decoding these signs and translating them into sociocultural discourses and practices contributes to the transformation of the sensemaking of values, beliefs, behaviors, relations with the real world, i.e., to the reproduction of cultural capital of the individuals engaged.

At present, visible symptoms of the virus, for example, which are quite similar to the symptoms of the seasonal flu, e.g., coughing, sneezing, etc., are decoded completely differently from their decoding in the pre-pandemic times. Before the outbreak, people would be seen as having 'just flue', but since the beginning of the outbreak, the same symptoms have been regarded as severely contagious and thus potentially life-threatening, which has dramatically transformed behavior and communicative patterns, social aesthetics and ethical standards. This "evolutionary scenario" might trigger "the production of the semiotic antibodies" (Venuleo, Gelo \& Salvatore, 2020, p. 127), increase social tension and thus, it stimulates moral blackmail, misbehavior or even racism towards people from different cultures. Interpreting these signs within the sensemaking framework of the pandemic (i.e., danger and anxiety-laden sensemaking) leads to mapping the new social world through effective rational functionalization of the external factors of ontological feelings and reactions. In other words, decoding such signs on the basis of "affective embodied meanings" (healthy/unhealthy, active/passive, safe/dangerous) (ibid., p. 121) that activate the semiosis of otherness and enemization in mindsets of social groups, leads to perceiving suspiciously infected people as socially irresponsible and, therefore, immoral since they presumably facilitate the virus/death spread in the community, which means destabilizing the social order and, thereby, the cultural milieus within this order. The pandemic changes the normative structure of the society and, as a result, the reading of behaviors.

This cultural and value-laden deviation underpinned by the new semiotic network of behaviors and objects around (e.g., wearing masks, interactional practices, lifestyle schemas, etc.) as well as their (new) functions will change or will at least add to the meaning of these behaviors and objects. These phenomena, their ideological associations and culture specific attitude towards their ramified meanings are likely to become a social and cultural convention, taken for granted globally and, therefore, incorporated into cultural capital across cultures and national borders.

\section{Conclusion}

The current coronavirus outbreak is different from other crises in that it is disrupting the prepandemic discourses, lifestyle and practices in every part of the world. The changes were initiated by medical institutions, upheld by governments and actively promoted by social and mass media: institutional discourse emphasized the globality and severity of the challenge, governmental discourse drilled into citizens' new stringent restrictions and rules, social and mass media discourse amplified the messages of the two discourses and generated fear culture.

The combination of the three discourses succeeded in reshaping social practices and mindsets of individuals and introduced a new perspective on the social structure, on the 'model citizen' and on the compulsory attributes of social responsibility. The pandemic also raised awareness of its own place in human history as extraordinary turning point. All these novelties are discernible in numerous new coinages created to verbalize new concepts.

Institutionalized, governmental, social and mass discourses ultimately acted upon human mindset and perception on the individual and collective level, modifying components of cultural capital. As a result, the perception of virus-related physiological reactions, social behaviors and interactional practices were reassessed and reappropriated in cultures across the world to the point 
when they were accepted as new universally shared cultural norm. Consequently, the pandemic has to a certain extent encouraged the convergence of cultural capital in quite different cultures, the most vivid example of this being the mask: it has become a universal feature, which was blatantly rejected by some cultures before the pandemic means for cultural/spatial discrimination and differentiation, but then adopted by these very cultures both locally and globally.

\section{References}

Abdul Rashid, S. M. R., Hassan, F., Md. Sharif, N., Abd Rahman, A., \& Mahamud, M. A. (2021). The Role of Digital Marketing in Assisting Small Rural Entrepreneurs Amidst Covid-19 Movement Control Order (MCO): A Case Study in Peninsular Malaysia.Academic Journal of Interdisciplinary Studies, 10(4), 70. https://doi.org/10.36941/ajis-2021-0099

Alkhamshi, S. S., bin Shalhoubm, H. abdulrahman, Hammad, M. A., \& Alshahrani, H. F. (2021). Covid-19 Pandemic: Psychological, Social and Economic Impacts on Saudi Society. Academic Journal of Interdisciplinary Studies, 10(3), 335. https://doi.org/10.36941/ajis-2021-0o88

Alter, L. (2020). Urban design after the coronavirus. Treehugger. Retrieved on January, 22, 2020, from: https://www.treehugger.com/urban-design-after-coronavirus-4848013

Alyeksyeyeva, I.O., Chaiuk, T.A., \& Galitska, E.A. (2020). Coronaspeak as Key to Coronaculture: Studying New Cultural Practices through Neologisms. International Journal of English Linguistics, 10 (6), 202-212. Doi: 10.5539/ijel.v10n6p202

Alexander, J. C. \& Smith, P. (2020). COVID-19 and symbolic action: global pandemic as code, narrative, and cultural performance. American journal of cultural sociology, 8, 263-269. DOI: https://doi.org/10.1057/s41290-020-00123-w

Barrett, L. F., Gross, J., Christensen, T. C., \& Benvenuto, M. (2001). Knowing what you're feeling and knowing what to do about it: mapping the relation between emotion differentiation and emotion regulation. Cognition and Emotion, 15 (6), 713-724, Doi: 10.1080/02699930143000239

Bauman, Z. (1999). Culture as Praxis. London: Sage.

Bourdieu, P. (1986). The forms of capital. In: J. Richardson (Ed.) Handbook of Theory and Research for the Sociology of Education (pp.241-58). Westport, CT: Greenwood.

Bourdieu, P. (1973). Cultural Production and Social Production. In R. Brown (Ed.) Knowledge, Education and Cultural Change (pp. 71-112). London: Tavistock.

Chaiuk, T. A. \& Dunaievska, O. V. (2020). Producing the Fear Culture in Media: An Examination on Coronavirus Discourse. Journal of History Culture and Art Research, 9 (2), 184-194. DOI: http://dx.doi.org/10.7596/taksad.v9i2.2636

Chen, X. (2012). Human development in the context of social change: introduction. Child Dev. Perspect., 6, 321325. https://doi.org/10.1111/j.1750-8606.2012.00259.X

Christakis, N. A. \& Fowler, J. H. (2009). Connected: The Surprising Power of our Social Networks and How They Shape our Lives. New York: Little, Brown.

Coombs, W. T., Fediuk, T., \& Holladay, S. J. (2007). Further explorations of post-crisis communication and stakeholder anger: the negative communication dynamic model. Paper presented at the 1oth International Public Relations Research Conference, South Miami, FL.

de la Sablonnière, R. (2017). Toward a Psychology of Social Change: A Typology of Social Change. Frontiers in psychology, 8, 397. https://doi.org/10.3389/fpsyg.2017.00397

de la Sablonnière, R., Taylor, D. M., Perozzo, C., \& Sadykova, N. (2009). Reconceptualizing relative deprivation in the context of dramatic social change: the challenge confronting the people of Kyrgyzstan. European Journal of Social Psychology, 39 (3), 325-345. https://doi.org/10.1002/ejsp.519

De Vries, P. (2020). Covid-19 Versus Japan's Culture of Collectivism. The Japan Times. Retrieved January 12, 2020 from: https://www.japantimes.co.jp/opinion/2020/o5/22/commentary/japan-commentary/covid-19-versusjapans-culture-collectivism/

Demertzis, N. \& Eyerman, R. (2020). Covid-19 as cultural trauma. American Journal of Cultural Sociology, 8, 428450. Doi: https://doi.org/10.1057/s41290-020-00112-z

Deopa, N. \& Forunato, P. (2020). Coronagraben. Culture and Social Distancing in Times of COVID-19. UNCTAD Research Paper, 49. Doi: 10.13140/RG.2.2.30665.98405.

Douglas, M. (1996). Thought Styles: Critical essays in good taste. London, UK: Sage Publications.

Epstein, S. (1994). Integration of the cognitive and psychodynamic unconscious. American Psychologist, 49, 709724. https://doi.org/10.1037/0003-066x.49.8.709 
Eriksen, T. H. (2001). Tyranny of the moment: Fast and slow time in the information age. Ann Arbor: University of Michigan Press.

Fairclough, N. (1992). Discourse and Social Change. Cambridge: Polity Press.

Fairclough, N. (2003). 'Political Correctness': The Politics of Culture and Language. Discourse E Society, 14(1), 1728. https://doi.org/10.1177/o957926503014001927

Florida, R. (2020). We'll Need to Reopen Our Cities. But Not Without Making Changes First. Bloomberg CityLab. Retrieved January, 22, 2020, from: https:/www.bloomberg.com/news/articles/2020-03-27/how-to-adaptcities-to-reopen-amid-coronavirus

Foucault, M. (1972). The Archaeology of Knowledge, trans. Sherican Smith, A.M., Tavistock, London (first published 1969).

Frame, A. \& Ihlen, Ø. (2018). Beyond the Cultural Turn: A Critical Perspective on Culture-Discourse within Public Relations. Public Relations and the Power of Creativity (Advances in Public Relations and Communication Management, 3, 151-162. https://doi.org/10.1108/S2398-39142018000oo03009

Greenfield, P. M. (2016). Social change, cultural evolution, and human development. Current opinion in psychology, 8, 84-92. https://doi.org/10.1016/j.copsyc.2015.10.012

Geertz, C. (1973). The Interpretation of Cultures. New York: Basic Books, Inc., Publishers.

Guiso, L., Sapienza, P., \& Zingales, L. (2006). Does Culture Affect Economic Outcomes? Journal of Economic Perspectives, 20 (2), $23-48$.

Hall, E. T. (1959). The Silent Language. New York: Anchor.

Harrison, E. (2020). Coronavirus: Dr Christian Jessen says Italians are using pandemic as an excuse for 'long siesta'. The Independent. Retrieved on February 19, 2020 from https://www.independent.co.uk/news/world/europe /coronavirus-dr-christian-jessen-italy-outbreak-embarrassing-bodies-siesta-a9399071.html

Honey-Rosés, J., Anguelovski, I., Chireh, V. K., Daher, C., Bosch, C. K., Litt, J. S., Mawani, V., McCall, M. K., Orellana, A., Oscilowicz, E., Sánchez, U., Senbel, M., Tan, X., Villagomez, E., Zapata, O., \& Nieuwenhuijsen, M. J. (2020). The impact of COVID-19 on public space: an early review of the emerging questions - design, perceptions and inequities, Cities E Health. Doi: https://doi.org/10.108o/23748834.2020.1780074

Hughes, R. A. (2020). Dr Christian Jessen apologies to Italians for 'long siesta' comment. Euro Weekly News. Retrieved February 19, 2020 from https://www.euroweeklynews.com/2020/03/25/dr-christian-jessenapologies-to-italians-for-long-siesta-comment/

Inou, A. (2021). "Hanasuna, tabero" Katsuragishi no koushiki kyara shichou ijiou no hasshinryoku de yobikake [Don't talk, eat!': Japan city mascot's posters urge dining out in silence]. https://mainichi.jp/articles/20210205/koo/oom/o40/300oooc

Lapuz, L. V. (1976). Culture change and psychological stress. The American Journal of Psychoanalysis, 36(2), 171176. https://doi.org/10.1007/BFo1248367

Leone, M. (2020). The Semiotics of the Medical Face Mask: East and West. Signs and Media, 1 (1), 40-70. Doi: https://doi.org/10.1163/25900323-12340004

Lyons, A. \& Kashima, Y. (2001). The reproduction of culture: Communication processes tend to maintain cultural stereotypes. Social Cognition, 19 (3), 372-394. https://doi.org/10.1521/soco.19.3.372.21470

Macionis, J. J., Jansson, M., \& Benoit, C. M. (2008). Society: The Basics. Toronto, ON: Pearson Education.

Mansor, N. R., Ab Rahman, A. H., Azza J. A. T., Abd Rashid, R., \& Ain Chua, N. (2021). New Norms of Online Teaching and Learning: Covid-19 Semester Experience for Universiti Malaysia Terengganu Students. Academic Journal of Interdisciplinary Studies, 10(4), 248. https://doi.org/10.36941/ajis-2021-0114

Mark, N. (2002). Cultural transmission, disproportionate prior exposure, and the evolution of cooperation. American Sociological Review, 67, 323-344. https://doi.org/10.2307/3088960

McDade, T. \& Worthman, C. (2004). Socialization Ambiguity in Samoan Adolescents: A Model for Human Development and Stress in the Context of Culture Change. Journal of Research on Adolescence, 14, 49-72. Doi:10.1111/J.1532-7795.2004.01401003.X

Osman, N. D., Hassan, F. M., Tajudin, A. A., \& @ Ali, M. N. A. (2021). COVID-19 as a National Security Issue in Malaysia: A Comparison with the Italian and Australian Perspectives. Academic Journal of Interdisciplinary Studies, 10(4), 261. https://doi.org/10.36941/ajis-2021-0115

Patterson, O. (2010). The Mechanisms of Cultural Reproduction: Explaining the Puzzle of Persistence. In J. R. Hall, L. Grindstaff, \& M.-C. Lo (Eds.) Handbook of Cultural Sociology (pp.139-151). New York: Routledge.

Ricca, M. (2020). Don't Uncover that Face! Covid-19 Masks and the Niqab: Ironic Transfigurations of the ECtHR's Intercultural Blindness. International journal for the semiotics of law - Revue internationale de semiotique juridique, 1-25. Advance online publication. https://doi.org/10.1007/s11196-020-09703-y 
Roberts, D. (2020). How to make a city livable during lockdown. Retrieved February 02, 2020, from: https://www.vox.com/cities-and-urbanism/2020/4/13/21218759/coronavirus-cities-lockdown-covid-19-brenttoderian

Ryall, J. (2020). How Japan's mask culture may have saved lives during coronavirus. DW. Retrieved January 12, 2020 from: https://www.dw.com/en/how-japans-mask-culture-may-have-saved-lives-during-coronavirus/a55321518

Salvatore, S., Fini, V., Mannarini, T., Valsiner, J., \& Veltri, G. A. (2019). Symbolic universes in time of (post)crisis. The future of European societies. Cham, Switzerland: Springer.

Sastry, S. \& Basu, A. (2020). How to Have (Critical) Method in a Pandemic: Outlining a Culture-Centered Approach to Health Discourse Analysis. Frontiers in Communication. Doi:10.3389/fcomm.2020.585954

Sebeok, T. A. (2001). Global Semiotics. Bloomington, Indiana: Indiana University Press.

Sperber, D. (1998). Explaining culture: A naturalistic approach. Oxford, UK: Blackwell.

Stinchcombe, A. (1968). Constructing Social Theories. Chicago. University of Chicago Press.

Swidler, A. (1986). Culture in Action: Symbols and Strategies. American Sociological Review, 51 (2), 273 - 286.

Tannen, D. (1997). Involvement as Dialogue: Linguistic Theory and the Relation between Conversational and Literary Discourse. In M. Macovsky (Ed.) Dialogue and Critical Discourse - Language, Culture, Critical Theory (pp.137-1570.) New York, Oxford: Oxford University Press.

Tashiro, A. \& Shaw, R. (2020). COVID-19 pandemic response in Japan: What is behind the initial flattening of the curve? Sustainability (Switzerland), 12(13). https://doi.org/10.3390/su12135250 